\title{
Naval Stores Extraction in Eastern North Carolina: The Historical Basis of Spatial Inequality within a Core Nation
}

\author{
Adam Driscoll ${ }^{1}$ \\ North Carolina State University \\ ardrisco@ncsu.edu \\ Edward L. Kick \\ North Carolina State University
}

\begin{abstract}
Within world-systems research there is an overwhelming tendency to treat nation-states as homogenous wholes. With some notable exceptions, this approach downplays the existence and operation of core-periphery relations on the sub-national level and the resultant inequality between different regions of nation-states. This study uses various complementary literatures in an integrative fashion to address this lacuna within the world-systems approach. We argue that uneven geographical development within core nations can at least partially be explained by the historical appropriation of natural capital; a universal process in which site-specific geographic factors and the larger political-economic context of the world-system interact, over time, to produce linked regions of relative accumulation and deprivation. To demonstrate the utility of this approach, we examine eastern North Carolina's history as the principal producer of naval stores for Great Britain's navy during Britain's ascension toward hegemonic status in the worldsystem during the eighteenth century. We highlight how those initial extractive activities functioned as a "de-generative sector," hindering the region's overall development. We argue generally for a synthetic approach to development theory and corresponding empirical examinations of modern and historical inequalities.
\end{abstract}

Key Words: Internal peripheries, extractive processes, regional economies

World-systems analysis, as initially formulated by Immanuel Wallerstein (1974), is a theoretical strand (Lakatos 1978) that examines how global processes of capital accumulation inherently generate inequality between those who exploit and those who are exploited. As noted by Wallerstein himself, the world-system is an integrated whole with a single (although highly

\footnotetext{
${ }^{1}$ We would like to thank Brett Clark, Laura McKinney, and Gretchen Thompson for their kind and insightful comments on earlier drafts of this paper. Additionally, Christopher Chase-Dunn, Wilma Dunaway, and Andrew Jorgenson all provided input at various junctures in this paper's formation. Finally, we would like to thank Jackie Smith and the two anonymous reviewers for their valuable feedback.
} 
complex) division of labor. As such, the world-system itself is the only appropriate unit of analysis. However, research within this perspective has overwhelmingly focused on the quantitative comparison of nation-states; treating these entities as homogenous wholes, rather than structured affiliations that encompass a wide range of peoples, geographic regions, and interests. This tendency downplays the operation of core-periphery relations at the subnational scale. As a number of critics have noted, structured inequality exists within nation-states as well as between them (Chase-Dunn 1980; Agnew 1987; Smith 1987; Taylor 1988; Hall 1989a, 1989b; Dunaway 1994, 1996a; Hanna 1995; Harvey 2006). Therefore, an occasionally observed and accurate conception of the world-system is probably that of a continuous network of power and dependency relationships that possesses sets of nested hierarchies (Chase-Dunn 1998). While states are important actors within this system, they are not the only relevant unit. Instead, regions are the sub-unit of the world-economy that may be best defined as engaging in core or peripheral activity (or both in the case of the semiperiphery) and consequently should be focused upon in world-systems analysis (Chase-Dunn 1998: 208).

While the world-systems approach acknowledges the region as a critical unit for study, the understanding of the origins and functioning of regional inequality requires further development. To address this, we augment world-systems arguments with complementary insights from the dependency and spatial inequality literatures, as well as the pioneering work of scholars such as Stephen Bunker and Paul Ciccantell (1994, 1999, 2003, 2005) and Jason Moore (2000a, 2000b, 2003, 2011). When these arguments are utilized together, the operation of coreperiphery relations within nation-states and the resulting geographic inequalities that occurs on the subnational level may be more effectively ascertained and analyzed. Such an integrative method of theory building can help cumulate knowledge into general explanatory principles (Collins 1989) and seeks to build a more accurate and comprehensive understanding of how the world operates, rather than validate one particular theorization at the expense of others (Merton 1973; Ritzer 1991). We argue that the historical appropriation of natural capital ${ }^{2}$ (e.g., raw materials) by core powers from dependent peripheries outside the core is a process replicated with peripheral areas within core nations. This dynamic explains much of the spatial inequality that has characterized the world-system to this day. We explore how the historical interaction of ecological and geographical factors with the greater political-economic context accounts for contemporary uneven development.

To demonstrate the utility of this approach, we present a case study in which eastern North Carolina's geographical suitability for naval stores (tar, pitch, and turpentine) production caused the area to be exploited by Great Britain as a peripheral source of natural resources during the eighteenth century. ${ }^{3}$ This locked the region into a path-dependent development strategy built around circumscribed extractive activities, structuring subsequent economic activity in ways that

\footnotetext{
${ }^{2}$ We are aware of the critiques that exist of the term "natural capital," which focus upon its implication that elements of the natural world are substitutable with other forms of capital to an unreal degree (Burkett 2003; Harvey 1993). While we acknowledge the merits of this critique and its relevancy for arguments against the reductionist attribution of economic value to the natural world, we use the term in this paper as it is a widely accepted means of conveying how natural resource endowments are a depletable source of wealth that can be transformed into other forms of capital.

${ }^{3}$ We acknowledge that the history of the region did not originate with the arrival of Europeans, and that there is a rich history of various world-systems that have emerged and declined before this area came into contact with the central world-system of European origin. For a theoretical framework of such world-systems see Chase-Dunn and Hall's (1997) comparative world-systems approach.
} 
stunted the region's development. Simultaneously, the extraction of naval stores contributed to Great Britain's ascension to hegemonic status in the world-system and arguably advantaged the semiperipheral northeastern colonies (and later states). Therefore, the naval stores industry provides a useful example of linked processes of extraction and accumulation generating uneven development at successively smaller levels.

Most immediately, we describe eastern North Carolina's geography and current state of relative underdevelopment. Following this, we develop our theoretical perspective more fully. We then analyze the rise of the British Empire, and its absolute dependence upon a reliable supply of naval stores for the warships that established and maintained its position at the head of the world-economy. We explore how that demand resulted in the rise of naval stores production in eastern North Carolina and how those activities conditioned subsequent economic development in the region, contributing to the current spatial inequality between that area and other parts of the state and nation. Finally, we offer conclusions and implications that, among other things, argue for future analyses of comparable situations across multiple sites within core nations of the world-system, broadening the expanse of the world-systems perspective.

\section{Eastern North Carolina}

North Carolina is physically divided into three regions, each of which possesses a unique geography and history. The western territory is comprised of the Smoky Mountains and contains a distinct Appalachian heritage. ${ }^{4}$ The red clay hills of the Piedmont region form the geographic center of the state and include both the "Research Triangle" (Raleigh, Durham, and Chapel Hill) and Charlotte areas. Our focus is on the Coastal Plain or "Tidewater" region, bounded by the Atlantic Ocean on the east and the Piedmont to the west (See Figure 1). The area is dominated by flat swampland and possesses sandy soil that, prior to the use of artificial fertilizers, was relatively infertile. This set the geographical stage for an early history of poor agricultural productivity. However, for millennia the region has contained extensive pine forests, which also cover much of the coastal plains of the southern United States. The make-up of these forests and the initially poor quality of the area's soils limited the production of food and fiber products and partially accounted for the path of development that led this region to form an extractive economy producing naval stores.

Contemporary eastern North Carolina is a region characterized by lower status across a range of economic and social dimensions, relative to the more-developed regions of the United States (see Table 1). It is overwhelmingly rural, and contains only one city with a population greater than 100,000 . There is some light manufacturing in the area, but the economy has historically been dependent upon agriculture and extractive industries such as fishing, mining, and pulpwood forestry (OPPNCDA 1990; Delia, Brockett, and Gauland 2002). The percentage of the region's earnings that come from the primary sector are more than twice that of the adjacent Piedmont and almost six times that of New England (U.S. Census 2011). Accordingly, income levels in eastern North Carolina are substantially lower than nearby areas. Nineteen of the forty-one counties in the region have poverty rates over eighteen percent, and ten of those fall under the USDA's definition of Persistently Poor, the only counties in the state to qualify as

\footnotetext{
${ }^{4}$ Interested readers can find studies and descriptions of the Appalachian region by Davis (2000), Dunaway (1996a, 1996b, 1994), Lewis, Johnson, and Askins (1978), and Walls (1978) among others.
} 
such (NCREDC 2004; USDA 2011). Thus, individuals who are born in eastern North Carolina face poorer life chances than those born in the more-developed areas within the United States. This study explores the basis for eastern North Carolina's relatively lower state of development in the economic activities of the colonial and antebellum eras.

Table 1: Demographic indicators for eastern North Carolina as compared to the averages for the Piedmont region and New England States

\begin{tabular}{cccc}
\hline & $\begin{array}{c}\text { New England* } \\
\text { Average }\end{array}$ & Piedmont Region & $\begin{array}{c}\text { Eastern North } \\
\text { Carolina }\end{array}$ \\
\hline Indicator & & & \\
\hline \% of Population in Poverty & $8.2 \%$ & $9.8 \%$ & $15.3 \%$ \\
Median Household Income & $\$ 48,195$ & $\$ 44,707$ & $\$ 34,465$ \\
Property Values & $\$ 161,270$ & $\$ 120,389$ & $\$ 91,956$ \\
$\%$ of Population in Rural & $19.4 \%$ & $31.1 \%$ & $48.5 \%$ \\
$\%$ of Population Af. Amer. & $5.9 \%$ & $22.2 \%$ & $29.6 \%$ \\
$\%$ of Pop. over 25 with a & $30.7 \%$ & $26.6 \%$ & $16.6 \%$ \\
Bachelor's Degree & & & \\
\hline
\end{tabular}

*Connecticut, Maine, Massachusetts, New Hampshire, Rhode Island, and Vermont.

All indicators are for the year 2000. Source: 2000 U.S. Census.

\section{Theoretical Perspective}

\section{Prolegomenon}

This study utilizes a synthetic theoretical framework that complements the world-system approach with concepts from the dependency and spatial inequality literatures. By integrating insights from the common ground found within multiple literatures, we are able to benefit from the various strengths of different approaches and avoid the premature dismissal of valid interpretations. Such an integrative strategy cumulates knowledge and builds theories that better understand and explain phenomena of interest, inventing "more and more powerful searchlights" that illuminate the real world more clearly (Popper 1966: 361). This approach possesses a distinct advantage in the generation of models with greater and broader explanatory power when compared to what we term "gladiator science" or a "theory-bashing" mindset (Lofland 1993). Gladiator science is the unfortunate tendency to pit a competing theorization's hypothesis (often singular and decontextualized) against one's own in hope that the contender will be felled (falsified) and the favored one left standing (validated) at the end of the empirical contest. Such a strategy leads to increased fractionation within the discipline and an overall narrowing of the applicability of different theoretical perspectives. However, gladiator science is a strategy that is heavily rewarded within our institutional system where distinction and recognition are favored over the selfless pursuit of knowledge (Merton 1973). Eschewing such a method, we answer the numerous calls for more theoretical integration (Collins 1989; Merton 1973; Ritzer 1991; Small 1994[1895]; Turner 2010) and draw from the complementary insights of several approaches within world-systems and related dependency approaches. 


\section{Theorization: Integrating Multiple Perspectives}

Our theoretical framework draws from multiple perspectives to broadly explain how uneven development has its historical origins in both foundational ecological dynamics and politicaleconomic relations. We argue that the historical appropriation of natural capital from one region by another creates different economic trajectories that, over time, result in spatial inequalities between historic sites of accumulation and historic sites of extraction. This process of appropriation, in which more-developed states and regions utilize resources from less-developed states and regions is an "irreducibly socio-ecological" one that can only be fully understood by examining the interactions between social and environmental factors (Moore 2011: 110). Understanding this process provides a basis for explaining the formation of spatial inequality (Hooks, Lobao, and Tickamyer 2007) on multiple scales. Importantly, our framework highlights the functioning of these mechanisms at the subnational level (i.e. eastern North Carolina), connecting broader relations of power and dependency to regional formations of unequal development.

As our initial point of departure we broadly proceed from the work pioneered by Stephen Bunker $(1984,1985,1992)$ and expanded upon by a number of his students and collaborators (e.g., Bunker and Ciccantell 2003, 2005; Leitner 2003, 2004; Priest 2003, 2007; Gellert 2010). While drawing from general arguments about the role of power and dependency relationships in creating unequal development, their approach emphasizes the global flow of raw materials as the primary dynamic of unequal development within the world-system. We also integrate a number of insights from the work of Jason Moore $(2000 \mathrm{a}, 2000 \mathrm{~b}, 2003)$, who examines the accumulation of capital as a socio-ecological process, driven by "the exhaustion of specific complexes of nature-society relations" (2011: 124). By blending concepts from world-systems analysis and the metabolic rift perspective (see Foster 1999, 2000), Moore presents his own unique integrative theory of capitalist world-ecology that, like Bunker and Ciccantell's, emphasizes the material basis of capital accumulation. Both perspectives view the depletion and degradation of environmental resources as a key motive for the expansion of the modern world-system into previously unincorporated regions (Leitner 2007).

Given that the process of accumulation is rooted in material processes of production, economies that successfully accumulate capital will be those that are best able to secure and control the flow of raw materials (Bunker 1992; O'Hearn 2005). Rural sociologists have gone as far as to state that natural capital "is the base on which all other capitals depend" (Flora and Flora 2008: 17). All productive activities require natural resources in some stage of refinement, and competitive expansion of production requires a corresponding increase in resource input. When local supplies have been exhausted, the "commodity frontier" must expand to incorporate new regions, labor, and modes of extraction (Moore 2000b, 2003). These new resources may be obtained through force (primitive accumulation) or, alternatively, by creating new trade relations that advantage the already dominant economy. Competition among nations to secure access to the raw materials necessary to support an expanding economy is one of the fundamental mechanisms driving the expansion of the capitalist world-economy and a nation or region's degree of success in that competition is the primary determinant of its economic trajectory (Moore 2003; Bunker and Ciccantell 2005; Harvey 2006).

The processes of raw material extraction and transport possess a basis in the geological and ecological properties of both the resource and the region of extraction (Bunker 1992; Cronon 2003). Therefore, explanations of the control and flow of resources must include relevant 
environmental variables along with political-economic ones (Harvey 1993; Moore 2003). A commodity's natural location, material form, and physical scarcity create issues rooted in physical principles (Bunker 1994). Different regions' initial endowments of natural capital structure the character of their incorporation into the world-system. Additionally, the physical basis of a resource can be degraded or destroyed through the processes of extraction itself (Bunker 1984). Once a socio-ecological system of extraction has been taxed to the point where profits begin to fall, capital is spurred to reorganize production and expand the commodity frontier to ensure continued accumulation (Moore 2000b). Accordingly, both the ascension of regions that successfully appropriate natural resources and the stagnation of those from which the resources are extracted possess a foundation in ecological dynamics.

The key driver of economic growth within an ascending economy is a strong generative sector, which is the portion of the economy that engages in core-like production and contains a number of forward and backward linkages which stimulate innovation and development across other sectors while fostering the growth of the over-all economy (Bunker and Ciccantell 2003). Generative sectors of rising economies often involve the procurement (and transport) of raw materials while stimulating economic activities that require increased supplies of said materials, simultaneously increasing both the supply of and the demand for resource extraction. Therefore, growth within generative sectors is dependent upon access to raw materials and encourages growth in activities that obtain them. Nations and regions with strong generative sectors function as sites of accumulation of natural capital and experience correspondingly rapid economic development (e.g., Dutch shipping, British warships and iron industries, U.S. shipbuilding and railroads).

While generative sectors within ascendant semiperipheral and core nations function to spur economic growth and the further acquisition of resources, this growth is directly linked to a corresponding underdevelopment that occurs in the peripheral regions that supply the raw materials. The global demand for specific commodities reorganizes local and regional modes of production and extraction within both internal and external resource peripheries (Moore 2000b). This reorganization creates extractive economies and conditions subsequent developmental pathways by degrading the physical environment and redistributing human populations in ways that limit future economic activity (Bunker 1984). These extractive economies have been described in the dependency literature as "disarticulated" (Baran 1957; Amin 1974). This term denotes a structural distortion that is characterized by weak or non-existent integration among unevenly developed economic sectors. Disarticulated economies suffer from "extraversion" (the domination of an economy by an external market orientation), where the export sector is more highly developed and uses more modern technology and capital intensive practices than the domestic sectors (Amin 1976). However, this developed sector of the economy is poorly linked to other sectors due to its reliance upon foreign capital, thus growth and investment in the export sector does not facilitate growth in other sectors (Breedlove and Armer 1997). We term such an economic activity a "de-generative sector," in that it stunts the over-all economic growth of the region that it characterizes.

De-generative sectors hinder the development of the local economy through a variety of mechanisms. The development of extraverted economies involves relatively little capital being transferred to the resource-rich nation or region (Baran 1957). Additionally, in a form of path dependency, what little capital is transferred is often "inflexibly sunk in technologies of extraction and transport," which only create external economies for further extractive industries (Bunker 2005: 6). De-generative sectors also reorganize human populations and labor forces in 
ways that limit future productive potentials. The displacement or elimination of indigenous populations from areas of extraction (Bunker 1984), along with a heavy reliance upon slave labor made possible through the simplification of both the labor process and the physical organization of the land itself (Moore 2003), reduce the pool of future laborers and consumers in a heavily exploited region.

There is also a stagnation in basic food production as land and labor are devoted toward the production of exports instead of staple crops (Baran 1957; Bunker 1985) and because cheap labor requires appropriately cheap food which can easily be provided by subsistence production within the traditional sector (de Janvry and Garramon 1977; de Janvry 1981). Finally, extractive industries tend to degrade the natural capital that they are based upon, depleting its availability for future use (Moore 2003; Gellert 2010). In this manner, de-generative sectors deplete their own conditions of production, leaving the region in which they are located poorer in foundational resources than it was before the extractive activity began (O'Conner 1998; Moore $2000 \mathrm{~b}$ ). Through the mechanisms outlined here, regions that are incorporated into the global economy through de-generative sectors built around resource extraction often fail to achieve sustainable economic growth.

Within world-systems and dependency approaches, the role of these linked processes of extraction and accumulation in generating uneven development has primarily been conceptualized and explored at the cross-national level. While notable exceptions exist that examine core-periphery dynamics at the subnational level - for example, Chase-Dunn's treatment of the antebellum South (1980, 1998: 210), Dunaway's studies of Southern Appalachia (1994, 1996a, 1996b), Hall's work on the U.S. Southwest (1989a, 1989b), and Cronon's (1991) and Robbins' (1994) accounts of the incorporation of the Western United States - a great deal more work is required in this understudied area. Rural sociologists have recently highlighted the existence of uneven development within core nations, particularly within the United States (Tickamyer 2000; Hooks, Lobao, and Tickamyer 2007). They use the term "spatial inequality" to identify differences in various characteristics of well-being and life chances that exist across several geographic regions and scales within the world-system. However, the approach has most explicitly focused upon uneven development across middle-range units of analysis within core nations (Lobao 2004). While studies of spatial inequality have done much to document and redirect focus onto developmental heterogeneity within core nations, an explicit theory of spatial inequality has yet to be developed (Lobao and Hooks 2007). We argue that the origins of spatial inequality can best be theorized through processes described by extant world-systems and dependency arguments.

Some have argued that the geographic "region" (spaces in which processes of production, labor, exchange, and consumption "hang together within an open system that nevertheless exhibits some kind of structural coherence" [Harvey 2006: 102]) is the most appropriate unit that can accurately be designated as engaging in core or peripheral activities (Smith 1987; Taylor 1988; Chase-Dunn 1998; Hall 2009). Accordingly, the historical appropriation of natural capital can occur between different regions within a core nation through mechanisms that closely approximate the ways in which it occurs between developed and developing nations. The regions within core nations from which raw materials are being extracted can contain de-generative sectors that stunt their development in the same manner that they stunt the development of peripheral nations. The resulting difference in development between the regions that are accumulating resources and the "internal peripheries" that are providing them creates spatial inequalities within nation states (Walls 1978). These processes of internal exploitation can even 
play a vital role in "bootstrapping" upwardly mobile semiperipheral states into higher positions within the world-system (Wright 1990; Chase-Dunn 1998).

\section{Empirical Analysis}

The proceeding is an account of eastern North Carolina's incorporation into the world-system as a region of naval stores extraction for the British Empire. We analyze the history of naval stores production in the region, focusing upon the manner in which the appropriation of this natural resource dually contributed to the rise of the British Empire and the lack of development in eastern North Carolina. While reviewing that history, we highlight the dynamics we have outlined above, paying particular attention to the interaction between social and ecological factors. In this way, we empirically test the degree to which our theoretical framework is reflected by the historical record.

\section{The British Empire and Naval Power: The Source of Demand for Naval Stores}

The British Empire has a rich history that has been well explored in a number of works. ${ }^{5}$ We engage that history to establish three facts: 1) naval power was a key factor in England's (and later Great Britain's) ${ }^{6}$ rise to global power, 2) access to sufficient supplies of naval stores was necessary for the establishment and maintenance of that naval dominance, and 3) a combination of geographical and political-economic factors ultimately drove Great Britain to look outward to supply said naval stores.

The Royal Navy was central to England's economic ascension and Great Britain's eventually attainment of global hegemony at the beginning of the nineteenth century due to both its strict military role and its related role in overseas trade. At the beginning of the "long sixteenth century" (Wallerstein 1974), when the modern (or central) world-system was emerging, England was a burgeoning world power, vying with the Dutch and the French to challenge and to ultimately replace the Spanish and Portuguese monopoly on colonization and overseas trade (Mancke 2009). The Dutch were able to initially overtake the Spanish in shipping and trade due to a competitive advantage in shipbuilding and ship designs that allowed for more economic transportation of bulk goods (Özveren 2000; Bunker and Ciccantell 2005). However, England was eventually able to supplant the Dutch through imperialistic naval might. The contentions of these various competing world powers across an approximately 300 -year period were marked by nearly continuous warfare.

Beginning in 1585, England initiated a series of wars with Spain, due in part to attempts by English seamen to break into the lucrative Spanish trade with the Americas as both merchants and pirates (Friel 2003: 92). These wars included constant raiding of Spanish towns, shipping, and overseas holdings, as well as epic naval battles, such as the defeat of the Spanish Armada in

\footnotetext{
${ }^{5}$ See Rose, Newton, and Benians' The Cambridge History of the British Empire (1960), Armitage and Braddick's The British Atlantic World, 1500-1800 (2002), and Julian Go's Patterns of Empire (2011). For a world-systems treatment of this history, see Wallerstein's The Modern World-System (1974) and The Modern World-System II (1980).

${ }^{6}$ England did not unify with Scotland until the Acts of Union in 1707 (Rose et al. 1960: 266); therefore we only refer to Great Britain as an entity after that point in time.
} 
1588 (Archibald 1968). The wedding of privateering, mercantilism, and warfare came to define the role of England's navy in supporting that nation's ascension to global dominance. Once the Dutch replaced the Spanish in dominance of overseas shipping at the end of the sixteenth century (Wallerstein 1980), they became England's chief rival for global control over ocean-based trade routes and a series of Anglo-Dutch wars were fought in the seventeenth century over these prospects. These wars centered on a series of naval struggles, and England's eventual victory was primarily based on their innovations in naval warfare technology and the expansion of the Royal Navy. By 1715 the British Royal Navy had 182 wooden ships on its books that exceeded 300 tons, making it the greatest naval power in the world by a substantial margin (Friel 2003: 131).

Accompanying these wars and Great Britain's rise as a military power was a general trend of first the Dutch and later the British assuming control of overseas trade. With Spain declining in dominance, the Spanish empire opened up as a market for British traders and colonists (Rose et al. 1960: 125-128). This trend resulted in the colonization of North America and the establishment of national trading companies such as the English East India Company in 1599. Following the conclusion of The War of the Spanish Succession, the British were able to enter into the lucrative slave trade, which had previously been dominated by the Spanish, Portuguese, and the Dutch (Friel 2003). The scope of the expanded trade and the acquisition of new colonies throughout both hemispheres reflected the Empire's economic rise, based to a significant degree on the global reach enabled by its command of the seas.

The success of the British Navy in both warfare and trade was dependent upon a tremendous growth in shipbuilding and an accompanying increase in demand for shipbuilding materials, including naval stores. The term "naval stores" originally referred to all materials used in building and maintaining ships (including timber and cloth). Later it came to solely denote tar, pitch, and turpentine, the three derivatives of pine resins used in making ships (Perry 1968). Tar is a sticky liquid produced by burning pine branches and logs slowly in a kiln. Tarred yarn formed the waterproof ropes for ships' rigging. When tar is boiled to remove some of the water, it becomes the thicker pitch, which was used as a sealant on ships, making their sides and bottoms watertight and extending the longevity of the hull (Özveren 2000). Finally, turpentine is a spirit distilled from living pine secretions which had only a few uses in the manufacture of ships. However, it was later applied to a wide variety of commercial purposes (paint thinner, rubber solvent, lamp oil), and grew to be the most heavily demanded naval store product (Butler 1998). While modern variants of these products can be artificially synthesized, up until the beginning of the twentieth century they could only be obtained from piney forests.

As early as the $1500 \mathrm{~s}$, a royal bounty was offered by England to encourage shipbuilding. Shipbuilding booms occurred during the Anglo-Spanish war of 1585-1603 and between 1595 and 1618, when 508 ships of 100 tons or more were built in England (Friel 2003: 115). This trend continued throughout the seventeenth century, as 22 men-of-war ships were built in 1654 alone (Özveren 2000: 32). The growth of the Royal Navy was the key generative sector behind Great Britain's ascension in that it created a number of linkages with other industries that spurred growth of the over-all economy while securing access to a range of external natural resources (Bunker and Ciccantell 2003, 2005). In addition to encouraging shipbuilding, the Royal Navy's need for warship armaments stimulated growth in Great Britain's fledgling iron industry, which would later become a vital industry during the period of British hegemony (Wallerstein 1980).

The emphasis on shipbuilding also created a need for the raw materials that supported it, including timber and naval stores. Initially England was able to meet its need for shipbuilding 
materials through domestic resources, but the concurrent timber demands of the shipping and iron industries, along with consumption for various domestic purposes (e.g., home heating), rapidly depleted native stocks (Albion 1926). The degradation of their domestic forests contributed to the English colonizing Ireland in the late $16^{\text {th }}$ century and exploiting Irish timberlands (Rose et al. 1960: 56). However, within approximately 100 years Ireland's "woods were used up to supply England with timber" (Wallerstein 1974: 281). By 1660, England was forced to look further outward to meet their demand for naval stores (Albion 1926). Here we see the dynamic of an expanding commodity frontier, where the ecological depletion of an essential natural resource in one region drives the incorporation of new regions to maintain profitable access to the commodity (Moore 2000b).

\section{The Naval Stores Act: Securing Raw Materials for British Naval Power}

As England attempted to secure an external source of naval stores, a series of historical developments led Great Britain to turn to its North American colonies to meet its shipbuilding supply needs: the breakdown of the Baltic tar trade, the rise of competitive manufactures in their northern American colonies, and the domination of parliament by the Whig party with their strong mercantilist policies. Initially, England was able to import shipbuilding supplies from Prussia and later, Sweden. However, by the $1690 \mathrm{~s}$, Swedish naval stores production had become monopolized by the Stockholm Tar Company, which subsequently raised prices (Silver 1990: 123). Additionally, Baltic naval stores trade was interrupted by the Great Northern War (17001721), further leaving the English in search of a new source (Özveren 2000: 66). At this time, England's dominant Whig party stressed that her colonies were to act as suppliers of raw materials for English manufacturing and markets for those processed goods (Airaksinen 1996). The Board of Trade noticed that the northern colonies were not operating within this mercantilist structure. Not only were they failing to provide adequate raw materials, but they were beginning to compete with English woolen manufactures (Rose et al. 1960: 572-574). In response, Parliament passed a series of laws and acts that were intended to return the colonies to the production of raw material commodities.

The combination of the break in Baltic naval stores trade and the Whig party's mercantilist designs for the northern colonies led to the passage of the 1705 Naval Stores Act, which provided a bounty of $£ 4$ per ton of tar and pitch and $£ 3$ per ton of rosin and turpentine produced in the New England and the "Middle Colonies" (Jensen 1955; Cook 1967). The purpose of this bounty was to offset the higher shipping costs colonial naval stores faced relative to those of Scandinavian manufacture. The act also classified naval stores as "enumerated commodities," meaning colonists could only export these products to England, and then only through English traders (Airaksinen 1996). Despite the incentive created by the bounty, the forests of the northern colonies were less suited to the expansive production of naval stores, due to previous timbering and a lack of resin-producing pines. ${ }^{7}$ Instead, for reasons developed in the following section, North Carolina became the primary source of naval stores, although many of those stores were exported through the northern colonies' ports in order to capitalize upon the bounty.

\footnotetext{
${ }^{7}$ In 1709, Great Britain sent 3,000 Palatine immigrants to New York with instructions to produce naval stores. However, the effort failed due to the scarcity of suitable pines, poor financing, and the German immigrants' preference for establishing independent settlements rather than laboring on large private estates. (Otterness 1994; Outland 2004: 14)
} 
Following the passage of the Naval Stores Act, the American colonies rapidly became Great Britain's principle source of tar and pitch. Previously production had been sporadic and modest in scale, but by 1715 exports of naval stores from the colonies were equal to those from the Baltic region (Silver 1990: 123) and in 1718 the colonies exported 82,084 barrels of pitch and tar - seven times that which Great Britain was receiving from Europe (Williams 1935; Cook 1967). The supply was briefly interrupted when the Naval Stores Act expired in 1725, but upon the bounty's restoration in 1729 the colonies quickly returned to their status as Great Britain's primary supplier, and production rebounded to the point where Great Britain started exporting surplus naval stores to other European powers (Outland 2004: 13). This supply continued until it was interrupted by the Revolutionary War (1775-83), at which point Great Britain was annually importing up to 135,000 barrels of colonial tar, pitch, and turpentine (Williams 1935). Thus, the Naval Stores Act was successful in promoting production in the colonies and freeing Great Britain from the Swedish monopoly.

\section{Eastern North Carolina and Naval Stores Production}

In order to more fully appreciate the role played by the naval stores industry in shaping eastern North Carolina's development, it is necessary to understand the causal forces that led to this industry's emergence in the region during the colonial era. In this section, we explore how the interaction among geographic, environmental, and political-economic factors created a socioecological complex that favored naval stores production in eastern North Carolina. The region's ecology was dominated by the type of pine tree best suited to naval stores production. When this natural capital endowment was combined with the economic incentive created by the Naval Stores Act and a lack of viable alternative industries, the socio-ecological stage was set for naval stores production.

At the time of colonization, the forests of the southeastern coastal plain consisted of over 80 percent longleaf pine trees (Pinus palustris). Due to its high resin levels, this species of pine is the most suitable for naval stores production of all trees. The southeastern coastal plain is an environment that favors the longleaf pine, relative to other species, due to its relatively infertile soil, sustained dry periods, and high winds. The longleaf pine possesses a long taproot that enables it to access nutrients and water that are beyond the reach of many plants' root structures. Additionally, the long taproot serves to anchor the longleaf against windy conditions, including hurricanes. Accordingly, these ecological features give the longleaf a natural advantage over other competing tree species (Outland 2004: 15-19) and the southeastern forests a comparative advantage in naval stores production.

An additional factor that accounts for the longleaf pine's predominance in the southeastern coastal plain is its high degree of resistance to fire (Silver 1990: 18). The combination of long protective needles and a deep root system that serves as a food reservoir in the event of needle loss makes young longleaf pines better able to survive low burning fires than rival species. Mature longleafs develop a layer of thick bark that serves as further protection. Routine fires consequentially eliminate less tolerant trees species and allow the longleaf to dominate the area (Heywood 1939). The southeastern forests were frequently exposed to fires, both natural and anthropogenic in origin. The natural fires were the result of frequent lighting storms and accumulated ground litter. Given that thunderstorms tend to be accompanied by precipitation, these fires burn slowly and low to the ground. The majority of the fires in the region, however, were induced by Native American peoples. The evidence that exists on fire 
history indicates that humans had been using fire to manage the landscape of the coastal plain as far back as 5,000 years ago to make it more conducive to their means of subsistence (Pyne 1982). ${ }^{8}$ An unintended consequence of this use of fire, however, was encouragement of the growth of the longleaf pine (Kalisz, Dorian, and Stone 1986).

While the actions of the indigenous peoples may have structured the environment and helped shape the post-colonization history of the region, their societies were severely disrupted by the arrival of Europeans and the subsequent incorporation of the native civilizations into the global capitalist economy. Similar to other indigenes, such as the Cherokee of Southern Appalachia (Dunaway 1994, 1996), the Native American tribes in the region that would become eastern North Carolina were initially incorporated into the world-economy through trade with the colonists in animal skins and food. However, as the English colonies expanded, the various indigenes either were eliminated or were driven from the area. ${ }^{9}$ So while the Native American tribes played a vital role in fostering the natural capital that provided the base of the naval stores industry in this region, their societies did not survive to play a role in the industry's development.

Given that the piney forests of the entire southeastern coastal plains were dominated by a species of pine particularly well suited to naval stores production, the question arises as to why these activities developed in the eastern part of North Carolina more so than other colonies within the pine belt (Virginia, South Carolina, and Georgia). This is explained by the presence of alternative commodities in the other colonies and their essential absence in North Carolina (Silver 1990: 123). The manufacture of naval stores was a labor intensive process with workers using hand tools and human power to gather the pine lightwood, build an earthen kiln, and extract the tar (in the case of tar and pitch) or to box the trees and extract the resins (in the case of turpentine) (Williams 1935). Virginia was initially encouraged by English officials to produce naval stores, but the higher returns to labor that could be obtained through tobacco production pulled Virginia colonists in that direction (Outland 2004: 11). Similarly, the cultivation of rice and indigo in South Carolina and Georgia offered more profitable uses for slave labor. While tar and pitch were produced in small quantities in those colonies, in relative terms they were never viable as an export commodity. North Carolina was sparsely populated and with its comparatively infertile soil, it was the poorest of the colonies (Perry 1968). Consequently, it lacked both the natural capital and the labor force to compete in the production of those other, more profitable commodities.

Although the production of naval stores in North Carolina dates as far back as 1608 , large-scale production did not take place until after the Naval Stores Act came into effect in 1705

\footnotetext{
${ }^{8}$ Fires kept the forests open, which encouraged the growth of grasses and shrubs that fed bison, deer, elk, and other grazing animals that the indigenous people hunted, while improving the production of edible berries, easing the gathering of nuts, and suppressing larger fires by clearing away potential fuel (Pyne 1982; Outland 2004: 17).

${ }^{9}$ The original English colony on Roanoke Island traded deer and buffalo skins and food with the Hatteras people, an Algonquian-speaking tribe that occupied the outer banks region (Lefler and Powell 1973: 7). Later English colonists, who migrated into the region from Virginia, encountered the Chowanoc (another Algonquian-speaking tribe) and the Tuscarora (an Iroquoian-speaking group) peoples and engaged them in similar trade relations, including the trade for land (Lefler and Powell 1973: 29-31). The Hatteras people were quite friendly with the English and eventually became fully assimilated into English society (Powell 1989: 21). The Chowanocs, while initially friendly with the colonists, later joined various Virginian tribes in war with the English and were ultimately defeated in 1677 (Powell 1989: 21-22). The Tuscarora people, in response to a wide range of insults and encroachments, declared war on all white colonists and nearly destroyed all white settlements in their territory. However, troops from South Carolina joined in the war and aided in the defeat of the Tuscarora in 1715, and the survivors left to join the Iroquorian Nation of New York (Lefler and Powell 1973: 67-79).
} 
(Silver 1990: 123). The bounty in the act boosted naval stores prices to the point where they were an economically viable commodity. Following its passage, manufacturing of those products blossomed in the region between the Cape Fear River in North Carolina and Charleston, South Carolina (see Figure 1). Between 1705 and 1718, the area exported 134,212 barrels of tar and pitch, a tonnage that exceeded that of any other product (Outland 2004: 20). Initially, production was largely carried out on plantations in each colony, whose owners possessed both large tracts of wooded land and slaves to work them. Slaves would work at crop cultivation during the growing season and naval stores production during the winter, "thus making sure the slaves had work all through the year" (Airaksinen 1996: 121). ${ }^{10}$ When the bounty was temporarily dropped in the late $1720 \mathrm{~s}$, the subsequent fall in prices drove most South Carolina producers out of naval stores and into the more profitable production of rice and indigo (Perry 1968).

Figure 1: Historical Map of Eastern North Carolina

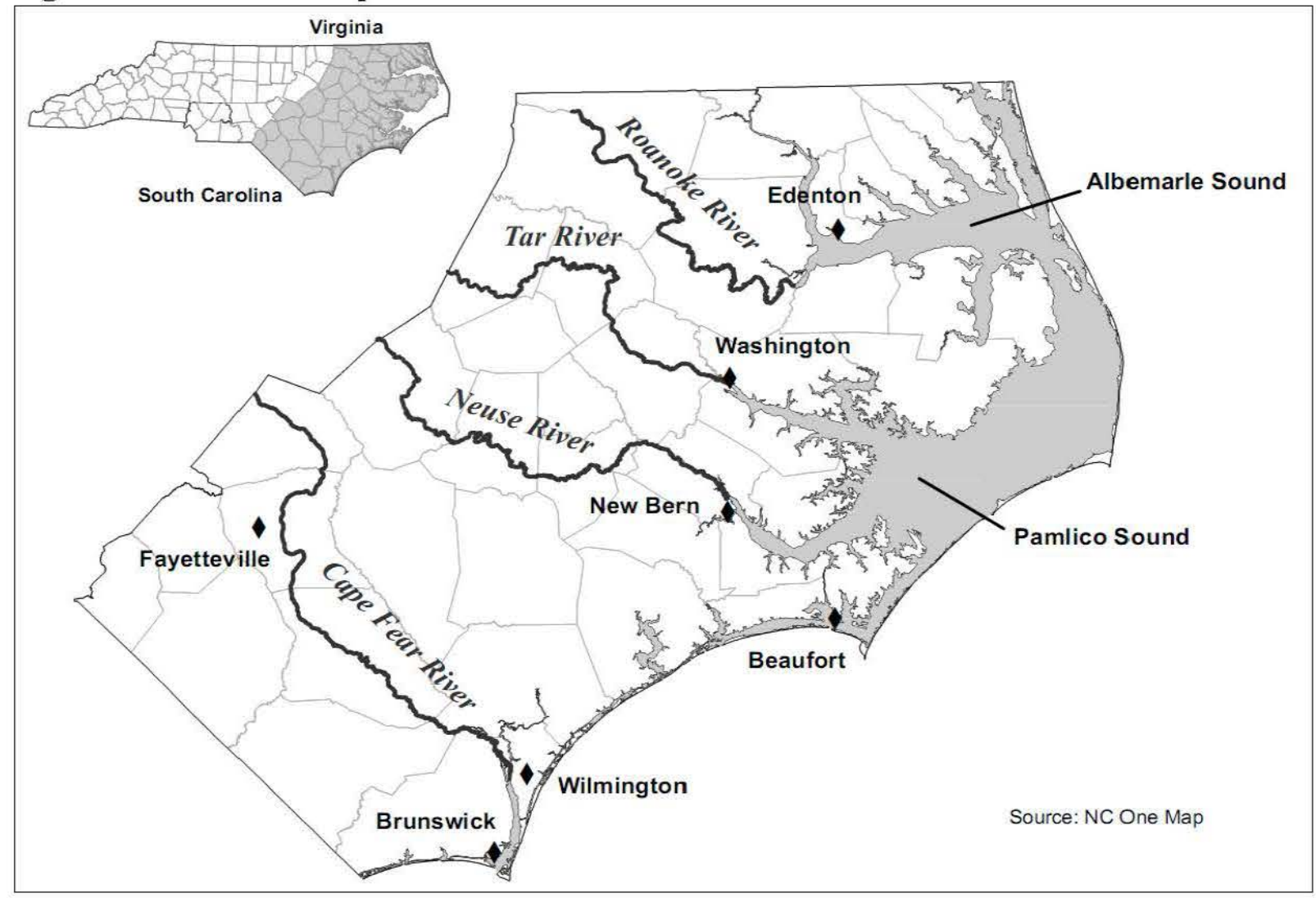

With the bounty's renewal in 1729 , part-time production continued on the plantations in the Cape Fear River Valley, where the river could provide transport down to the ports of Wilmington and Brunswick (Williams 1935; see Figure 1). However, in this region naval stores had to compete with the more profitable timber industry and largely remained a secondary economic activity. At the same time, a second center of naval stores production emerged in the sparsely settled Albemarle region in the north-eastern part of the colony. Unlike the plantationstyle extraction in the Southeast, production in this area was primarily carried out by small-scale

\footnotetext{
${ }^{10}$ The production of naval stores as an off-harvest activity allowed for the year-round utilization of labor, a
} condition that fostered the use of slave labor over part-time wage labor (Moore 2000b). 
farmers and backwoodsmen who used income from naval stores to supplement their own subsistence agriculture. These early settlers lacked the capital resources to purchase large slave labor forces or sizeable timber tracts. Therefore, naval stores extraction occurred at a small-scale, part-time level with the work being largely provided by the settlers themselves, as so few of them owned slaves (Perry 1968). The Albemarle naval stores manufacturers faced transportation challenges, as roads in the region were limited and Edenton, the most convenient port in the area, was much less accessible from the sea than the southern ports of Beaufort, Brunswick, and Wilmington (see Figure 1). Small-scale producers from the Albemarle region gradually spread southward into the Washington and New Bern areas and migrated up the Tar and Neuse rivers. With better transport options, the area west of the Pamlico Sound rapidly outgrew the Albemarle region and joined the Cape Fear River Valley as a central nexus of production (Outland 2004: 31). In 1775, North Carolina alone was exporting up to 130,000 barrels of tar and pitch annually (Williams 1935).

The Revolutionary War (1775-83) created a temporary upheaval in the industry, but eastern North Carolina continued to dominate North American production of naval stores, even without the bounty. By 1787, production in the region had rebounded to pre-war levels and North Carolina remained the primary American naval stores producer. While trade with Great Britain had been disrupted, eastern North Carolina was freed from the bounds of mercantilism and began to export naval stores to other countries. Additionally, the end of the war saw a revival in American shipbuilding and at the turn of the century the northern states had replaced Great Britain as the principal buyer of North Carolina naval stores (Özveren 2000: 67).

\section{Naval Stores Production as a De-generative Sector}

To this point we have described how Great Britain's rise to global power was dependent upon the strength of its navy and how the concurrent demand for ships and shipbuilding supplies led it to seek external sources of naval stores. Eastern North Carolina's ecology and lack of competing industries made it an ideal region to provide the necessary raw materials. British economic policies drove the development of an extractive naval stores industry in the region, carried out through the part-time labor of slaves and yeoman small farmers. In this section we will explore the various mechanisms through which that industry constituted a de-generative sector, initiating a path dependent development trajectory for the region that stunted its future economic growth and partially accounts for its current state of relative underdevelopment. The mechanisms involved include a failure to form economic linkages, the lack of substantial capital accumulation, the development of extractive infrastructure, size limitations on the future labor force, the diversion of resources away from basic food production, and the degradation of the region's natural capital.

Throughout the colonial and antebellum periods, the naval stores industry constituted a major portion of the economy of eastern North Carolina. However, the industry failed to bring any lasting economic development to this rural area, as evidenced by the relative lack of industry today (Outland 2004). One of the primary shortcomings of this industry as a source of development was its extraverted, disarticulated nature and the corresponding absence of either forward or backward linkages with other economic activities within the region. Being a labor intensive process, the extraction of naval stores had minimal capital and materials requirements (Cook 1967). Therefore, it required no substantial inputs from the region and failed to stimulate growth in any industries that would provide building blocks or tools for production (backward 
linkages). Additionally, the shipbuilding industries of Great Britain (and later the New England States) that generated the demand for naval stores were entirely absent in eastern North Carolina (Powell 1989). Thus, none of the products of this industry were being utilized by other economic enterprises in the region (forward linkages). The absence of these economic linkages is characteristic of what we term a de-generative sector and helps explain why this industry did not stimulate future growth. Without any substantial connections between the manufacture of naval stores and other economic activities in the region, the industry failed to circulate resources throughout the area and promote any sustained economic development in eastern North Carolina.

In addition to failing to stimulate other economic sectors, the naval stores industry also hindered the formation of a capital base in the region that could be converted into other industries. As described above, the production of naval stores was carried out by laborers working with hand tools, which required very little by way of investment capital (Butler 1998: 10-12). As a source of supplemental income for yeoman farmers' subsistence, the export of naval stores did not involve a large transfer of wealth to the producers (Airaksinen 1996). Instead, much like pre-industrial agriculture and other extractive industries, the manufacture of naval stores required little initial capital investment and provided few capital returns (Outland 2004). By failing to facilitate the transfer of capital into the region, the industry failed to provide the most fundamental base for future economic growth. However, in a form of path dependent development, the naval stores industry did lay the foundation for a future investment of capital in the region in the form of a transport infrastructure.

In the early $1800 \mathrm{~s}$ a series of new applications for turpentine led to a spike in global demand for it. As eastern North Carolina was already the leading producer of turpentine, much of the initial increased production came from that region and by 1860 the area was the world's leading producer (Perry 1968). This expanded production was accompanied by a number of improvements and investments in transportation infrastructure. The Cape Fear River underwent improvement during the $1850 \mathrm{~s}$ in the form of a series of dams and locks that extended the navigable portion of the river. Additionally, in the $1840 \mathrm{~s}$ and $1850 \mathrm{~s}$ the construction of a series of plank roads that radiated out from Fayetteville (the inland center of the turpentine trade) provided access to large areas of the pine forest that had previously been too remote for profitable naval store production (Outland 1996: 33). The biggest transportation innovation connected to the naval stores industry was the construction of a number of railroads that terminated at Wilmington, the primary port for turpentine export. The largest of these, the Wilmington and Weldon, was the longest railroad in the world at the time (Outland 2004: 52). This entire transport infrastructure, while constituting an investment of built capital into the region, created external economies that were only suitable for future extractive industries (i.e. timber, cotton, and tobacco). Therefore, the inflexible capital that the naval stores industry did eventually bring to eastern North Carolina only served to further lock the area into the primary production of basic raw materials, a path that has historically failed to generate relative development (Frank 1969; Amin 1976; Bunker 1985; Freudenburg 1992).

The extraction of naval stores also reduced the potential for future economic growth by severely degrading the natural capital on which the industry depended. Turpentine production in eastern North Carolina relied upon the destructive box system (chopping a wide, shallow hole into the base of a tree) which injured and weakened trees, leaving them susceptible to wind, disease, drought, infestation, and fires. Boxed trees were three times more likely to fall during a hurricane or strong windstorm, and the boxes served as sites for fungal growth and decay as well as damaging infestations by a number of wood-boring insects (Perry 1968). The most destructive 
factor, however, was the increased vulnerability of boxed pine trees to fire. White settlers had continued the Native American practice of using low burning fires to open forests, encourage grasses, and reduce pests. But while fires cultivated the growth of healthy longleaf trees, they often destroyed those that had been boxed (Cook 1967). All of these debilitating consequences of the boxing process led to the widespread destruction of eastern North Carolina's pine forests. In this way, rather than create a stable base for future economic activity, the industry exploited a particular resource until it was exhausted and left ruined forests behind in which "the still-visible mounds of ancient tar kilns [give] silent testimony to colonial exploitation" (Silver 1990: 129).

In addition to destroying its own conditions of production, the production of naval stores also sharply limited the development of eastern North Carolina's labor force. As we mentioned before, the settlement of the area involved the displacement of most of the indigenous people, largely eliminating them as potential workers. Instead, the extraction of naval stores was carried out almost exclusively by slave labor in the southern part of the region and a combination of slaves and free white yeomen in the north. When the pine forests collapsed in the second half of the nineteenth century, the larger producers shifted their operations to virgin timber stands further south, taking their slaves with them (Outland 2004: 111-121). The slaves who remained in the area and their progeny would face a future of marginalization and disadvantage as an under-privileged and secondary work force that continues to this day. ${ }^{11}$ Only the few descendants of the white yeomen would go on to function as full participants in the labor market. Thus, the production of naval stores in eastern North Carolina largely failed to cultivate sufficient human capital to later transform the region.

The naval stores industry also hampered future economic development in eastern North Carolina by drawing both land and labor away from the production of basic food stuffs. Particularly during the turpentine boom of the early $1800 \mathrm{~s}$, the production of naval stores was more profitable than basic agriculture and a large number of the region's farmers and planters diverted their efforts from the fields and into the forests. As a result, the region became a net importer of food, with the area's importation of both corn and bacon quadrupling as the naval stores industry expanded (Outland 2004: 109). This lack of self-sufficiency in basic food production was a hindrance on the region's economic growth as it pulled money out of local circulation, thus negating any possible Keynesian multiplier effects. The situation runs parallel to the contemporary world economy, where dependent rural economies produce agriculture for export rather than subsistence, resulting in severe domestic hunger (McMichael 2009).

While the production of naval stores was one of the primary economic activities for eastern North Carolina during the colonial era, through the constellation of mechanisms outlined above, it failed to promote, and in substantial ways hindered, any sustained economic growth. The failure of the region to move forward stands in stark contrast to the rapid growth exhibited by a number of other areas within the United States. Other regions with more strongly articulated economies during the colonial and antebellum eras were able to diversify their economic activities around local generative sectors such as shipbuilding and trade in the Northeast, manufacturing in the Ohio River Valley, iron works in the Lehigh Valley, and railroads in the

\footnotetext{
${ }^{11}$ The history of the exploitation (an understatement, we concede) of blacks in the south, initially as slaves and later as second-class workers is a subject of tremendous nuance, detail, and argumentation that largely falls outside of the scope of this paper. (For an overview of such see Wimberley and Morris [1997, 2002]) We certainly acknowledge the uniqueness and importance of the racial dynamic, but focus here on the manner in which both white and black laborers were used as vehicles in a process that stripped the region of its natural wealth while enriching others, typically located on the outside.
} 
Midwest. The economies of these regions were not dominated by export-oriented extractive activities that degraded their natural capital and led to path dependent development in future extractive activities. Unencumbered by a dominant de-generative sector, these regions developed a diverse range of well-articulated agricultural activities and manufacturing industries that served as a stable base for capital accumulation, population growth, and the development of human capital. However, eastern North Carolina, inhibited by a lack of capital, an extraction-oriented infrastructure, and a degraded base of natural capital, continued to specialize in primary sector activities and fell behind the more developed areas within the nation. Having provided Great Britain with an essential factor for its rise to power, the area received in return a legacy of economic stagnation.

\section{Discussion and Conclusions}

In this paper we have drawn from multiple approaches within the world-systems and dependency perspectives to argue that the historic appropriation of natural capital is a key dynamic that links processes of deprivation and accumulation to generate spatial inequality at multiple levels. As developed nations and regions exhaust the socio-ecological complex that provides them with the raw materials needed for production, they are forced to expand the commodity frontier to incorporate new peripheral sources of natural capital (Moore 2000b). Generative sectors in the developed regions increase the acquisition of natural resources, aiding in the accumulation of capital and economic growth in that region. The corresponding de-generative sectors in the peripheral regions from which the resources are being extracted stunt economic development in that area through a range of mechanisms. These interconnected processes of accumulation and extraction result in very different economic trajectories for the two linked regions and ultimately create spatial inequalities between them.

In our case study of eastern North Carolina's naval stores industry, Great Britain's reliance upon naval power as both a generative sector for its economy and as a key factor for its rise to global domination created a tremendous demand for shipbuilding materials, including naval stores. The exhaustion of domestic forest resources forced Great Britain to seek out external supplies of naval sources. A combination of mercantilist trade policies and politicaleconomic factors made securing naval stores from the European continent troublesome for Britain. Instead, in a process that is fairly representative of the colonial era, Great Britain turned to its colonies to supply the needed resources. With the appropriate natural capital and a lack of alternative economic options, eastern North Carolina became the region from which Great Britain extracted its naval stores. Naval stores production was a de-generative sector in eastern North Carolina that hindered economic development in that region. Thus, Great Britain's rise to power was founded upon the appropriation of eastern North Carolina's natural capital; the extraction of which contributed to a legacy of stunted development and the current spatial inequality that exists between that region and other parts of the state, nation, and world-system.

Rather than view the history of eastern North Carolina as an isolated account, we argue that it is part of a broader global dynamic in which the appropriation of natural capital resources from the relatively powerless peripheries throughout the world-system by the relatively powerful industrial centers of the global economy has been a central mechanism in generating spatial inequality, both globally and locally. These historic processes can be seen operating at the international levels with the extraction of furs from Canada (Innis 1956), as well as rubber and 
iron from the Amazon basin (Bunker and Ciccantell 2005). They are also evident within developed nations as noted with the extraction of furs, coal, and timber from rural Appalachia (Hanna 1995; Dunaway 1996, 1994; Davis 2000); timber from northwestern Wisconsin (Leitner 2003); copper from Michigan's Upper Peninsula (Leitner 2004); and timber, mineral, and agricultural resources from the western United States (Cronon 1991; Robbins 1994).

In all of these instances, core powers of the world-system create extractive industries in peripheries (which may be foreign or within the core nation itself), facilitating the shift of natural capital from those peripheries to the centers of accumulation within the core. These mechanisms are grounded in the ecology of both regions, as well as the global political-economic structure of the time period. The end result is that the peripheries are left with degraded natural capital and a disarticulated economy, severely reducing prospects for future growth. These linked processes of extraction and accumulation are a fundamental dynamic in creating spatial inequality at both the inter- and sub-national levels.

Our study has utilized a synthetic theoretical framework in which related but seemingly disparate approaches were treated in an integrative fashion, rather than in a competitive one. By highlighting the shared principles among dependency and world-systems approaches and the spatial inequality literature, we are able to better understand the historical processes that generate inequality across a range of spatial scales and units. We argue that future work should continue this process of theoretical synthesis. If others continue working in this direction, drawing from multiple theoretical strands and disciplines, we will be able to further our understanding of global inequality. This strategy is a distinct improvement over competitive gladiator science that serves to further fragment our discipline into smaller and smaller camps that acknowledge outside work less and less. As Albion Small ([1895]1994: xvi) stated in the first issue of The American Journal of Sociology, "analytic and microscopic scholarship is abortive without the complementary work of the synthetic scholar who builds minute details into comprehensive structures."

In addition to future theoretical efforts, there is a need for further empirical work that assesses the accuracy of our theoretical framework. This current study illuminates but one aspect of the historical mosaic of exploitation that peripheral regions have undergone worldwide. A single case study cannot establish a general pattern, but may suggest the existence of such and provide incentive for further exploration. Other potential case studies abound within the United States itself, along with other core nations. The historical appropriation of natural capital is a universal dynamic that occurs on multiple levels and consequentially needs to be studied as such. Particularly, the degree to which it accounts for instances of spatial inequality within core nations is a subject of great interest that has not been sufficiently studied. Exposing these mechanisms at work within other core nations would support the validity of the theoretical approach advanced here and increase our understanding of the origins of unequal development as a whole. There is also much room for quantitative analyses at various subnational levels which, if historical data limitations can be overcome, could greatly improve our grasp of the global flow of natural resources and how it relates to global power and dependency relationships. The historical appropriation of natural capital is a highly complex process that needs to be understood at a far deeper and more comprehensive level than has previously been attempted. In many ways, these dynamics underlie the recent and long-term history of inequality for the entire world. 


\section{References}

Agnew, John. 1987. The United States in the World-Economy: A Regional Geography. Cambridge: Cambridge University Press.

Airaksinen, Mikko. 1996. "Tar Production in Colonial North America." Environment and History 2: 115-125.

Amin, Samir. 1974. Accumulation on a World Scale: A Critique of the Theory of Underdevelopment, Vol. land 2. New York: Monthly Review Press.

-----. 1976. Unequal Development. New York: Monthly Review Press.

Albion, Robert Greenhalgh. 1926. Forests and Sea Power: The Timber Problem of the Royal Navy, 1652-1862. Cambridge, MA: Harvard University Press.

Archibald, E.H.H. 1968. The Wooden Fighting Ship in the Royal Navy AD 897-1860. London: Blandford Press.

Armitage, David and Michael J. Braddick. The British Atlantic World, 1500-1800. New York: Palgrave Macmillan.

Baran, Paul A. 1957. The Political Economy of Growth. New York: Monthly Review Press.

Breedlove, William L., and J. Michael Armer. 1997. "Dependency, Techno-Economic Heritage, Disarticulation, and Social Development in Less Developed Nations." Sociological Perspectives 40(4): 661-680.

Bunker, Stephen G. 1984. "Modes of Extraction, Unequal Exchange, and the Progressive Underdevelopment of an Extreme Periphery: The Brazilian Amazon, 1600-1980." American Journal of Sociology 89: 1017-1064.

-----. 1985. Underdeveloping the Amazon. Chicago, IL: University of Chicago Press.

-----. 1992. "Natural Resource Extraction and Power Differentials in a Global Economy." Pp. 61-84 in Understanding Economic Process, edited by S. Ortiz and S. Lees. Lanham, MD: University Press of America.

-----. 1994. "The Political Economy of Raw Materials Extraction and Trade." Pp. 437-50 in Industrial Ecology and Global Change, edited by R. Socolow, C. Andrews, F. Berkhout, and V. Thomas. New York: Cambridge Press.

-----. 2005. "How Ecologically Uneven Development Put The Spin on the Treadmill of Production." Organization and Environment 18(1): 38-54.

Bunker, Stephen G. and Paul S. Ciccantell. 1994. "The Evolution of the World Aluminum Industry." Pp. 39-68 in State, Firms, and Raw Materials: The World Economy and Ecology of Aluminum, edited by B. Barham, S. G. Bunker, and D. O'Hearn. Madison: The University of Wisconsin Press.

-----. 1999. "Economic Ascent and the Global Environment: World-Systems Theory and the New Historical Materialism." Pp. 107-22 in Ecology and the World-System, edited by W. L. Goldfrank, D. Goodman, and A. Szasz. Westport, CT: Greenwood Press.

-----. 2003. "Generative Sectors and the New Historical Materialism: Economic Ascent and the Cumulatively Sequential Restructuring of the World Economy." Studies in Comparative International Development 37(4): 3-30.

-----. 2005. Globalization and the Race for Resources. Baltimore: John Hopkins University Press.

Burkett, Paul. 2003. "Natural Capital, Ecological Economics, and Marxism." International Papers in Political Economy 10(3): 1-61. 
Butler, Carroll B. 1998. Treasures of the Longleaf Pines: Naval Stores. Shalimar, FL: Tarkel Publishing.

Chase-Dunn, Christopher. 1980. "The Development of Core Capitalism in the Antebellum United States: Tariff Politics and Class Struggle in an Upwardly Mobile Semiperiphery." Pp. 189-230 in Studies of the Modern World-System. Edited by A. J. Bergesen. New York: Academic Press.

-----. 1998. Global Formation: Structures of the World-Economy, Updated Edition. New York: Rowman and Littlefield Publishers, Inc.

Chase-Dunn, Christopher and Thomas D. Hall. 1997. Rise and Demise: Comparing WorldSystems. Boulder, CO: Westfield Press.

Collins, Randall. 1989. "Sociology: Proscience or Antiscience?" American Sociological Review 54(1): 124-39.

Cook, Richard C. 1967. "Naval Stores: The Forgotten Industry In Tar Heel State." Naval Stores Review and Terpene Chemicals 77: 8-9.

Cronon, William. 1991. Nature's Metropolis: Chicago and the Great West. New York: W.W. Norton and Company.

-----. 2003. Changes in the Land: Indians, Colonists, and the Ecology of New England. New York: Hill and Wang.

Davis, Donald Edward. 2000. Where There Are Mountains: An Environmental History of the Southern Appalachians. Athens, GA: The University of Georgia Press.

de Janvry, Alain. 1981. The Agrarian Question and Reformism in Latin America. Baltimore: The Johns Hopkins University Press.

de Janvry, Alain and Carlos Garramon. 1977. "Laws of Motion of Capital in the CenterPeriphery Structure." Review of Radical Political Economics 9(2): 29-38.

Delia, Albert A., Richard Brockett, and Dana Jackson Gauland. 2002. Eastern North Carolina's Economy: The Economic Impact of Five Sectors--Manufacturing, Government, Military, Agriculture, and Tourism. East Carolina University Regional Development Services, Regional Development Institute. Greenville, NC.

Dunaway, Wilma. 1994. "The Southern Fur Trade and the Incorporation of Southern Appalachia into the World-Economy, 1690-1763." Review 17(2): 215-42.

-----. 1996a. The First American Frontier: Transition to Capitalism in Southern Appalachia, 1700-1860. Chapel Hill: The University of North Carolina Press.

-----. 1996b. "The Incorporation of Mountain Ecosystems into the Capitalist World-System." Review 19(4): 355-81.

Foster, John Bellamy. 1999. "Marx's Theory of Metabolic Rift: Classical Foundation for Environmental Sociology." American Journal of Sociology 105(2): 366-405.

-----. 2000. Marx's Ecology: Materialism and Nature. New York: Monthly Review Press.

Frank, Andre Gunder. 1969. Capitalism and Underdevelopment in Latin America. New York: Monthly Review Press.

Freudenburg, William R. "Addictive Economies: Extractive Industries and Vulnerable Localities in a Changing World Economy." Rural Sociology 57(3): 305-332.

Flora, Cornelia Butler and Jan L. Flora. 2008. Rural Communities: Legacy and Change, $3^{\text {rd }}$ Edition. Boulder, CO: Westview Press.

Friel, Ian. 2003. Maritime History of Britain and Ireland c. 400-2001. London: British Museum Press. 
Gellert, Paul K. 2010. "Extractive Regimes: Toward a Better Understanding of Indonesian Development." Rural Sociology 71(1): 28-57.

Go, Julian. 2011. Patterns of Empire: The British and American Empires, 1688 to the Present. New York: Cambridge University Press.

Hall, Thomas D. 1989a. Social Change in the Southwest, 1350-1880. Lawrence: University Press of Kansas.

-----. 1989b. "Is Historical Sociology of Peripheral Regions Peripheral?" Pp. 349-372 in Studies of Development and Change in the Modern World, edited by M. T. Martin and T. R. Kandal. New York: Oxford Press.

-----. 2009. "Puzzles in the Comparative Study of Frontiers: Problems, Some Solutions, and Methodological Implications." Journal of World Systems Research, XV(1):25-47.

Hanna, Stephan P. 1995. "Finding a Place in the World- Economy: Core-periphery Relations, the Nation-State and the Underdevelopment of Garrett County, Maryland." Political Geography 14(5): 451-472.

Harvey, David. 1993. "The Nature of Environment: The Dialectics of Social and Environmental Change." Pp. 1-51 in Socialist Register 1993, edited by L. Panitch and R. Miliband. London: Merlin.

-----. 2006. Spaces of Global Capitalism: Towards a Theory of Uneven Geographical Development. New York: Verso.

Heywood, Frank. 1939. "The Relation of Fire to Stand Composition of Longleaf Pine Forests." Ecology 20(2): 287-304.

Hooks, Gregory, Linda A. Lobao, and Ann R. Tickamyer. 2007. "An Agenda for Moving a Spatial Sociology Forward." In The Sociology of Spatial Inequality, edited by L. A. Lobao, G. Hooks, and A. R. Tickamyer. Albany: State University of New York Press.

Innis, Harold A. 1956. The Fur Trade in Canada: An Introduction to Canadian Economic History. Canada: University of Toronto Press.

Jensen, Merrill, ed. 1955. English Historical Documents IX, American Colonial Documents to 1776. New York: Oxford University Press.

Kalisz, Paul J., Alan W. Dorian, and Earl L. Stone. 1986. "Prehistoric Land-Use and the Distribution of Longleaf Pine on the Ocala National Forest, Florida: An Interdisciplinary Synthesis." The Florida Anthropologist 39(3): 183-193.

Lakatos, Imre. 1978. The Methodology of Scientific Research Programmes: Philosophical Papers, Volume 1. Edited by J. Worrall and G. Currie. New York: Cambridge University Press.

Lefler, Hugh T., and William S. Powell. 1973. Colonial North Carolina: A History. New York: Charles Scribner's Sons.

Leitner, Jonathan. 2003. "North American Timber Economy: Log Transport, Regional Capitalist Conflict, and Corporate Formation in Wisconsin's Chippewa Basin, 1860-1900." Review XXVI(2): 173-219.

-----. 2004. "The Political Economy of Raw Materials Transport from Internal Periphery to Core in the Early $20^{\text {th }}$ Century US: The Calumet and Hecla Copper Company's Struggle for Market Access, 1922-39." Journal of World-Systems Research X(2): 397-435.

----. 2007. "An Incorporated Comparison: Fernand Braudel's Account of Dutch Hegemony in a World-Ecological Perspective." Review XXX(2): 97-135.

Lewis, Helen M., Linda Johnson, and Donald Askins. 1978. Colonialism in Modern America: The Appalachian Case. Boone, NC: Appalachian Consortium Press. 
Lobao, Linda A. 2004. "Continuity and change in place stratification: Spatial inequality and middle-range territorial units." Rural Sociology 69(1): 1-30.

Lobao, Linda A., and Gregory Hooks. 2007. "Advancing the Sociology of Spatial Inequality: Space, Places, and the Subnational Scale.” In The Sociology of Spatial Inequality, edited by L. A Lobao, G. Hooks, and A. R. Tickamyer. Albany: State University of New York Press.

Lofland, John. 1993. "Theory-bashing and Answer-improving in the Study of Social Movements." The American Sociologist 24(2): 37-58.

Mancke, Elizabeth. 2009. "Empire and State." In The British Atlantic World, 1500-1800, edited by D. Armitage and M. J. Braddick. New York: Palgrave Macmillan.

McMichael, Philip. 2009. "A Food Regime Analysis of the "World Food Crisis." Agriculture and Human Values 26(4): 281-295.

Merton, Robert K. 1973. The Sociology of Science: Theoretical and Empirical Investigations. Chicago: The University of Chicago Press.

Moore, Jason W. 2000a. "Environmental Crises and the Metabolic Rift in World-Historical Perspective." Organization \& Environment 13(2): 123-157.

-----. 2000b. "Sugar and the Expansion of the Early Modern World-Economy: Commodity Frontiers, Ecological Transformation, and Industrialization." Review 23(3): 409-433.

-----. 2003. "The Modern World-System as Environmental History? Ecology and the Rise of Capitalism." Theory and Society 32: 307-377.

-----. 2011. "Ecology, Capital, and the Nature of Our Times: Accumulation and Crisis in the Capitalist World-Ecology." Journal of World-Systems Research XVII(1): 108-147.

North Carolina Rural Economic Development Center. 2004. Economic \& Social Trends Affecting Rural North Carolina. Raleigh, NC.

O'Connor, James. 1998. Natural Causes: Essays in Ecological Marxism. New York: The Guilford Press.

O'Hearn, Denis. 2005. "Cycles of Accumulation, Crisis, Materials, and Space: Can Different Theories of Change Be Reconciled?" Pp. 113-137 in Nature, Raw Materials, and Political Economy: Research in Rural Sociology and Development, edited by P.S. Ciccantell, D.A. Smith and G. Seidman. Amsterdam: Elsevier JAI.

Office of Policy and Planning, North Carolina Department of Administration. 1990. Regional Directions: Economic Trends in North Carolina. Raleigh, NC.

Otterness, Philip. 1994. "The New York Naval Stores Project and the Transformation of the Poor Palatines, 1710-1712." New York History 75(2): 133-156.

Outland, Robert B. III. 1996. "Slavery, Work, and the Geography of the North Carolina Naval Stores Industry, 1835-1860." Journal of Southern History 62(1): 27-56.

-----. 2004. Tapping the Pines: The Naval Stores Industry in the American South. Baton Rouge, LA: Louisiana State Press.

Özveren, Y. Eyüp. 2000. "Shipbuilding, 1590-1790.” Review XXIII(1): 15-86.

Perry, Percival. 1968. "The Naval-Stores Industry in the Old South, 1790-1860." Journal of Southern History 34: 509-26.

Popper, Karl. 1966. Objective Knowledge. Oxford: Oxford University Press.

Powell, William S. 1989. North Carolina Through Four Centuries. Chapel Hill: The University of North Carolina Press.

Priest, Tyler. 2003. Global Gambits: Big Steel and the U.S. Quest for Manganese. Westport, CT: Greenwood Press. 
Priest, Tyler. 2007. "Extraction Not Creation: The History of Offshore Petroleum in the Gulf of Mexico." Enterprise \& Society 8(2): 227-267.

Pyne, Stephen J. 1982. Fire in America: A Cultural History of Wildland and Rural Fire. Princeton, NJ: Princeton University Press.

Ritzer, George. 1991. Metatheorizing in Sociology. Lexington, MA: Lexington Books.

Robbins, William G. 1994. Colony and Empire: The Capitalist Transformation of the American West. Lawrence: University Press of Kansas.

Rose, J. H., A. P. Newton, and E.A. Benians (eds.). 1960. The Cambridge History of the British Empire, Volumes I and II. Cambridge: Cambridge University Press.

Silver, Timothy. 1990. A New Face on the Countryside: Indians, Colonists, and Slaves in the South Atlantic Forests, 1500-1800. New York: Cambridge University Press.

Small, Albion. 1994[1895]. "The Era of Sociology." American Journal of Sociology 100: ixxxiii.

Smith, Carol A. 1987. "Regional Analysis in World-Systems Perspective: A Critique of Three Structural Theories of Uneven Development." Review X(4): 597-648.

Taylor, Peter J. "World-Systems Analysis and Regional Geography." The Professional Geographer 40(3): 259-265.

Tickamyer, Ann R. 2000. "Space Matters! Spatial Inequality in Future Sociology." Contemporary Sociology 29(6): 805-813.

Turner, Jonathan H. 2010. Theoretical Principles of Sociology: Volume I, Macrodynamics. New York: Springer.

U.S. Census. 2011. U.S. Census Bureau Home Page. Retrieved October 20, 2011 (www.census.gov).

U.S. Department of Agriculture. 2011. "Rural Income, Poverty, and Welfare: Poverty Geography." United States Department of Agriculture, Economic Research Service.

Retrieved September 27, 2011 (http:/www.ers.usda.gov/Briefing/incomepovertywelfare/povertygeography.htm)

Wallerstein, Immanuel Maurice. 1974. The Modern World System: Capitalist Agriculture and the Origins of the European World-Economy in the Sixteenth Century. New York: Academic Press.

-----. 1980. The Modern World System II: Mercantilism and the Consolidation of the European World-Economy. New York: Academic Press.

Walls, David S. 1978. "Internal Colony or Internal Periphery? A critique of current models and alternative formulation." In Colonialism in Modern America: The Appalachian Case, edited by H.M. Lewis, L. Johnson, and D. Askins. Boone, NC: Appalachian Consortium Press.

Wimberley, Ronald C. and Libby V. Morris. 1997. The Southern Black Belt: A National Perspective. Lexington, KY: TVA Rural Studies.

-----. 2002. "The Regionalization of Poverty: Assistance for the Black Belt South?" Southern Rural Sociology 18(1): 294-306.

Williams, Justin. 1935. "English Mercantilism and Carolina Naval Stores, 1705-1776." Journal of Southern History 1: 169-185.

Wright, Gavin. 1990. "The Origins of American Industrial Success, 1879-1940." The American Economic Review 80(4): 651-68. 